\title{
Review of Impact and Handling of Potential Antihypertensive Drug Interactions in Chronic Kidney Disease Patients
}

\section{(Review Dampak dan Penanganan Potensi Interaksi Obat Golongan Antihipertensi pada Pasien Penyakit Ginjal Kronis)}

\author{
Ni Made Susilawati ${ }^{*}$, Eli Halimah ${ }^{1}$, Siti Saidah ${ }^{2}$ \\ ${ }^{1}$ Departemen Farmakologi dan Farmasi Klinik, Fakultas Farmasi, Universitas Padjadjaran, Sumedang, Jawa Barat, \\ Indonesia. \\ ${ }^{2}$ Instalasi Farmasi Rumah Sakit Umum Pusat Dr.Hasan Sadikin Bandung, Bandung, Jawa Barat, Indonesia. \\ *E-mail: susilawati.nmd@gmail.com
}

Article Info:

Received: 10 November 2020

in revised form: 16 February 2021

Accepted: 3 March 2021

Available Online: 4 March 2021

Keywords:

Drug Interactions

Antihypertensive

Chronic Kidney Disease

Corresponding Author:

Ni Made Susilawati

Departemen Farmakologi dan

Farmasi Klinik

Fakultas Farmasi

Universitas Padjadjaran

Sumedang

45363

Indonesia

email: susilawati.nmd@gmail.com

\begin{abstract}
Drug interaction is a type of Drug-Related Problems (DRPs) that can eventually increase morbidity and mortality rates. CKD patients have a significant risk of developing polypharmacy due to comorbid diseases and pharmacokinetics' alteration. The literature review was conducted by exploring all of the articles related to the drug interaction using drug interaction analysis program in CKD patients, which obtained from three databases, namely Google Scholar, PubMed, and Science Direct, using several keywords combination. Based on the comprehensive reviews conducted, it is known that the most common effects of antihypertensive drug interactions in CKD patients are decreasing effects of antihypertensive drugs, hypotension, and hyperkalemia. Handling management used for the emergence of potential drug interactions is based on the severity of the drug interactions and complete knowledge of the patients' clinical condition. The management of drug interaction by monitoring blood pressure, diuresis, and potassium levels; Monitor the related effect symptoms; Monitor the fluid and body weight; Monitor the kidney and heart function. On the condition where the handling management of potential drug interactions is not carried out, elevated morbidity and mortality rates are the risks of complications arising from the drug interactions.
\end{abstract}

How to cite (APA $6^{\text {th }}$ Style):

Susilawati, N.M., Halimah, E., Saidah, S.,(2021). The Impact And Handling Of Potential Antihypertensive Drug Interactions In Chronic Kidney Disease Patients. Jurnal Farmasi Galenika :Galenika Journal of Pharmacy (e-Journal), 7(1), 39-53. doi:10.22487/j24428744.2021.v7.i1.15332 


\begin{abstract}
ABSTRAK
Interaksi obat merupakan bagian dari masalah terkait obat yang berpotensi dapat meningkatkan morbiditas dan mortalitas. Pasien PGK memiliki risiko yang besar untuk mengalami polifarmasi akibat banyaknya penyakit komorbid dan perubahan farmakokinetik. Pembuatan ulasan literatur dilakukan dengan pencarian artikel interaksi obat menggunakan program analisis interaksi obat pasien PGK pada 3 database yaitu Google Scholar, PubMed, dan Science Direct dengan menggunakan beberapa kombinasi kata kunci. Berdasarkan hasil pencarian diketahui efek yang paling banyak berpotensi muncul pada pasien PGK akibat interaksi obat golongan antihipertensi yaitu penurunan efek obat antihipertensi, hipotensi dan juga hiperkalemia. Penanganan yang dilakukan untuk potensi interaksi obat yang muncul ialah didasarkan atas derajat keparahan interaksi obat serta pemahaman atas kondisi klinis pasien. Penanganan interaksi obat ialah melalui pemantaan tekanan darah, diuresis, dan kadar kalium; Pemantauan gejala dari efek yang bersangkutan; Pemantauan cairan dan berat badan; Pemantauan fungsi ginjal dan jantung. Apabila penanganan potensi interaksi obat tidak dilakukan maka berisiko menyebabkan peningkatan morbiditas dan mortalitas akibat komplikasi yang muncul akibat interaksi obat tersebut.
\end{abstract}

Kata kunci: Interaksi Obat, Antihipertensi, Penyakit Ginjal Kronis.

\title{
INTRODUCTION
}

Chronic kidney disease (CKD) is one of the leading causes of death worldwide that on the $17^{\text {th }}$ leading cause of death in 1990 and on the $12^{\text {th }}$ in 2017 (Bikbov et al., 2020). As stated in the WHO data, cardiovascular disease is the highest cause of mortality among other Non-Communicable Diseases (NCDs) worldwide in 2016 (World Health Organization, 2020). The relative risk of mortality caused by cardiovascular disease in the CKD patients undergoing hemodialysis is 20 times compared to the general population (Cozzolino et al., 2018). Thus, CKD indirectly contributes to increased mortality due to cardiovascular disease. The complexity of comorbid diseases in CKD patients causes the patient to experience polypharmacy by receiving five or more drug therapy with 12 or more doses for a day to treat the comorbid diseases and inhibiting the progression of the CKD (Hassan, Al-Ramahi, Aziz, \& Ghazali, 2009). Drug-related problems (DRPs) significantly correlate with the higher number of drug therapy used in treating CKD patients (Belaiche, Romanet, Allenet, Calop, \& Zaoui, 2012). Therefore, polypharmacy in the treatment of CKD patients could increase the incidence of experiencing DRPs.

Drug interaction is one of the DRPs types. Several studies have reported that the high prevalence of potential drug interactions that can occur in CKD patients is more than 50\% (Marquito, Fernandes, Colugnati, \& Paula, 2014; Okoro \& Farate, 2019; Raddad et al., 2016). Besides, several studies have also reported that antihypertensive drug classes that contribute the most to cause drug interaction in the combination therapy of CKD treatment with the prevalence of not less than 50\% include AngiotensinConverting Enzyme (ACE) Inhibitor, Angiotensin II Receptor Blocker (ARB), Calcium-Channel Blocker (CCB), and Diuretic. Adverse Drug Reaction (ADR) resulting from antihypertensive drug interaction could deteriorate drug effectiveness and safety for patients (Busari, Oreagba, Oshikoya, Kayode, \& Olayemi, 2019; Chinwendu, Joda, Oyetunde, \& Udezi, 2017; Marquito et al., 2014). Drug interaction mechanisms could occur either by pharmacokinetic or pharmacodynamic, that will affect 
drug levels in the blood and drug effectiveness. However, in CKD patients, alteration of pharmacokinetic profile could affect drugs entered in the body (Hakim, 2016).

A review of the antihypertensive drug interaction mechanism through pharmacokinetic and pharmacodynamic mechanisms had been discussed and reported previously (Maas \& Böger, 2003). Pharmacokinetics profile alteration and polypharmacy in CKD patients drug therapy will increase the risk of drug interactions that will cause ADR (Belaiche et al., 2012; Hakim, 2016; Olumuyiwa, Akinwumi, Ademola, Oluwole, \& Ibiene, 2017; Raddad et al., 2016). Therefore, this review aims to provide an overview of the impact and handling of antihypertensive drug interactions in CKD patients based on the extensive review from several updated research conducted in the last ten years.

\section{METHODS}

The study review was conducted by exploring all of the published articles obtained from databases: Google Scholar, PubMed, and Science Direct. The article search was using several related keywords combinations, for instance in the Google Scholar and Science Direct using keywords "drug-drug interaction" and "chronic kidney disease", while with PubMed using keywords "drug-drug interaction ", "drug interaction", "chronic kidney failure", "chronic renal insufficiencies", "disease, end stage renal", and "chronic kidney disease". The exclusion criteria: The article not published in period 2010 to 2020, the article is not a research article, an article duplication, the article is not in the English language, the article is not a study in CKD patients, and the article is not related to drug interaction analysis using drug interaction analysis program. The research article related to drug interaction analysis using drug interaction analysis program in CKD patients is the inclusion criteria.

\section{RESULTS AND DISCUSSION}

\section{Process and Result of Research Article Selection}

The total number of research articles identified from the three databases was 4.722 articles. After the screening process, 13 articles were included in this review based on the inclusion and exclusion criteria (Figure 1). 


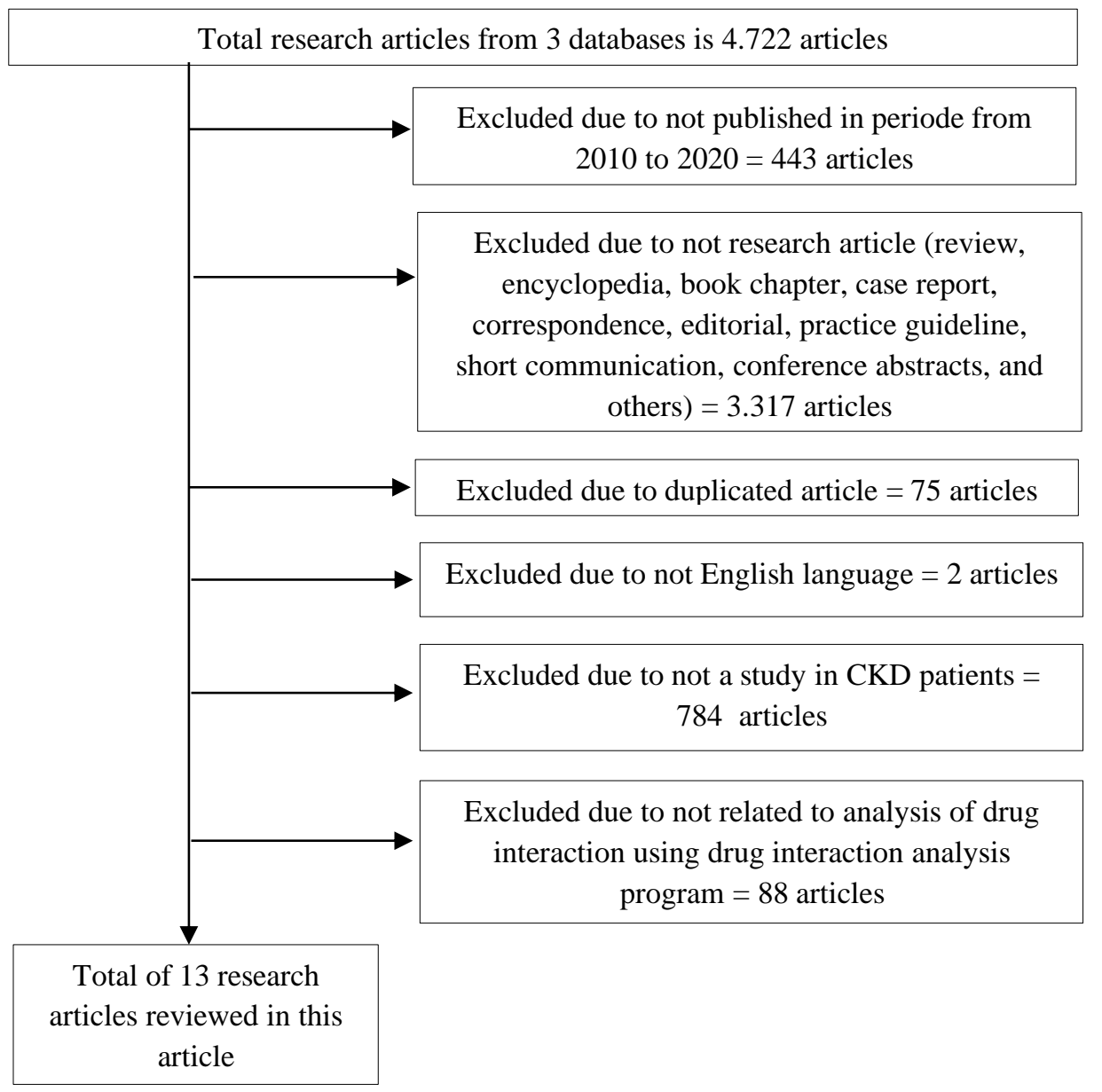

Figure 1. Process of Article Screening

Information about potential drug interactions in CKD patients based on drug interaction program analysis can be seen in the following table.

Table 1. Antihypertensive Drug Interactions with Other Drugs

\begin{tabular}{|c|c|c|c|c|c|}
\hline \multicolumn{6}{|c|}{ Micromedex $(N=373)$} \\
\hline \multicolumn{2}{|c|}{ Drug Pairs } & Severity & $\begin{array}{l}\text { Number of } \\
\text { Drug }\end{array}$ & Effect & Reference \\
\hline \multicolumn{6}{|c|}{ Drug Interaction Between ACE Inhibitor and Other Drug ( $\mathrm{N}=149)$} \\
\hline Captopril & Allopurinol & Major & 24 & $\begin{array}{l}\text { Hypersensitivity } \\
\text { reactions }\end{array}$ & \multirow{3}{*}{$\begin{array}{l}\text { (Marquito et } \\
\text { al., 2014) }\end{array}$} \\
\hline Enalapril & Allopurinol & Major & 21 & $\begin{array}{l}\text { Hypersensitivity } \\
\text { reactions }\end{array}$ & \\
\hline Enalapril & Erythropoietin & Minor & 10 & $\begin{array}{l}\text { Increased dose of } \\
\text { Erythropoietin to } \\
\text { maintain hematocrit } \\
\text { levels }\end{array}$ & \\
\hline Lisinopril & Erythropoietin & Unknown & 20 & Unknown & \multirow{2}{*}{$\begin{array}{l}\text { (Busari et } \\
\text { al., 2019) }\end{array}$} \\
\hline Lisinopril & Aspirin & Moderate & 38 & $\begin{array}{l}\text { Decreased effect of } \\
\text { Lisinopril }\end{array}$ & \\
\hline
\end{tabular}




\begin{tabular}{|c|c|c|c|c|c|}
\hline Lisinopril & Metformin & Moderate & 36 & $\begin{array}{c}\text { Increased risk of } \\
\text { hypoglycemia }\end{array}$ & \\
\hline \multicolumn{6}{|c|}{ Drug Interaction Between Beta Blocker and Other Drug $(\mathrm{N}=10)$} \\
\hline Atenolol & $\begin{array}{l}\text { Calcium } \\
\text { Carbonate }\end{array}$ & Minor & 10 & $\begin{array}{c}\text { Decreased effect of } \\
\text { Atenolol }\end{array}$ & $\begin{array}{l}\text { (Busari et } \\
\text { al., 2019) }\end{array}$ \\
\hline \multicolumn{6}{|c|}{ Drug Interaction Between CCB and Other Drug $(\mathrm{N}=64)$} \\
\hline Amlodipine & Ciprofloxacin & Moderate & 12 & $\begin{array}{c}\text { Increased effect of } \\
\text { Amlodipine }\end{array}$ & \multirow{5}{*}{$\begin{array}{c}\text { (Saleem, } \\
\text { Masood, \& } \\
\text { Khan, 2017) }\end{array}$} \\
\hline Amlodipine & Prednisolone & Moderate & 11 & $\begin{array}{l}\text { Decreased effect of } \\
\text { Amlodipine }\end{array}$ & \\
\hline Amlodipine & Carbamazepine & Major & 6 & $\begin{array}{l}\text { Decreased effect of } \\
\text { Amlodipine }\end{array}$ & \\
\hline Amlodipine & Aspirin & Moderate & 6 & $\begin{array}{l}\text { Increased risk of } \\
\text { gastrointestinal } \\
\text { hemorrhage and } \\
\text { antagonism of } \\
\text { hypotensive effect }\end{array}$ & \\
\hline Amlodipine & Simvastatin & Major & 4 & $\begin{array}{l}\text { Increased effect of } \\
\text { Simvastatin and risk } \\
\text { of myopathy }\end{array}$ & \\
\hline Nifedipine & Carbamazepine & Contraindication & 3 & $\begin{array}{l}\text { Decreased effect of } \\
\text { Nifedipine }\end{array}$ & \multirow{4}{*}{$\begin{array}{l}\text { (Marquito et } \\
\text { al., 2014) }\end{array}$} \\
\hline Nifedipine & $\begin{array}{l}\text { Phenytoin } \\
\text { sodium }\end{array}$ & Contraindication & 1 & $\begin{array}{l}\text { Decreased effect of } \\
\text { Nifedipine and } \\
\text { increased toxicity of } \\
\text { Phenytoin Sodium }\end{array}$ & \\
\hline Nifedipine & Phenobarbital & Contraindication & 1 & $\begin{array}{l}\text { Decreased effect of } \\
\text { Nifedipine }\end{array}$ & \\
\hline Nifedipine & Metformin & Minor & 20 & $\begin{array}{l}\text { Increased absorption } \\
\text { of Metformin }\end{array}$ & \\
\hline \multicolumn{6}{|c|}{ Drug Interaction Between Diuretic and Other Drug $(\mathrm{N}=150)$} \\
\hline Furosemide & Aspirin & Moderate & 106 & $\begin{array}{l}\text { Decreased diuretic } \\
\text { and antihypertensive } \\
\text { effect of furosemide }\end{array}$ & $\begin{array}{l}\text { (Marquito et } \\
\text { al., 2014) }\end{array}$ \\
\hline Furosemide & $\begin{array}{l}\text { Insulin human } \\
\text { regular }\end{array}$ & Moderate & 4 & $\begin{array}{l}\text { Increased risk of } \\
\text { hypoglycemia }\end{array}$ & $\begin{array}{l}\text { (Saleem et } \\
\text { al., 2017) }\end{array}$ \\
\hline Furosemide & Aspirin & Moderate & 40 & $\begin{array}{l}\text { Decreased diuretic } \\
\text { and antihypertensive } \\
\text { effect of Furosemide }\end{array}$ & $\begin{array}{l}\text { (Busari et } \\
\text { al., 2019) }\end{array}$ \\
\hline \multicolumn{6}{|c|}{ Lexicomp $(\mathrm{N}=440)$} \\
\hline \multicolumn{6}{|c|}{ Drug Interaction Between ACE Inhibitor and Other Drug $(\mathrm{N}=34)$} \\
\hline Lisinopril & Heparin & Moderate & 34 & Hiperkalemia & $\begin{array}{l}\text { (Olumuyiwa } \\
\text { et al., 2017) }\end{array}$ \\
\hline \multicolumn{6}{|c|}{ Drug Interaction Between Beta Blocker and Other Drug $(\mathrm{N}=25)$} \\
\hline Atenolol & $\begin{array}{l}\text { Calcium } \\
\text { Carbonate }\end{array}$ & Minor & 25 & Not Reported & $\begin{array}{l}\text { (Raddad et } \\
\text { al., 2016) }\end{array}$ \\
\hline \multicolumn{6}{|c|}{ Drug Interaction Between CCB and Other Drug $(\mathrm{N}=146)$} \\
\hline Amlodipine & $\begin{array}{l}\text { Calcium } \\
\text { Carbonate }\end{array}$ & Moderate & 32 & $\begin{array}{c}\text { Decreased effect of } \\
\text { Amlodipine }\end{array}$ & $\begin{array}{l}\text { (Olumuyiwa } \\
\text { et al., 2017) }\end{array}$ \\
\hline Amlodipine & $\begin{array}{l}\text { Calcium } \\
\text { Carbonate }\end{array}$ & Moderate & 114 & Not Reported & $\begin{array}{l}\text { (Raddad et } \\
\text { al., 2016) }\end{array}$ \\
\hline \multicolumn{6}{|c|}{ Drug Interaction Between Diuretic and Other Drug $(\mathrm{N}=235)$} \\
\hline Furosemide & Folic acid & Minor & 63 & $\begin{array}{l}\text { Increased renal } \\
\text { clearance of Folic } \\
\text { Acid }\end{array}$ & $\begin{array}{l}\text { (Olumuyiwa } \\
\text { et al., 2017) }\end{array}$ \\
\hline
\end{tabular}




\begin{tabular}{|c|c|c|c|c|c|}
\hline Furosemide & $\begin{array}{c}\text { Calcium } \\
\text { Carbonate }\end{array}$ & Minor & 49 & $\begin{array}{c}\text { Increased renal } \\
\text { clearance of Calcium }\end{array}$ & \\
\hline Hydrochlorothiazide & Folic acid & Minor & 35 & $\begin{array}{l}\text { Increased renal } \\
\text { clearance of Folic } \\
\text { Acid }\end{array}$ & \\
\hline Furosemide & Aspirin & Moderate & 74 & Not Reported & $\begin{array}{l}\text { (Raddad et } \\
\text { al., 2016) }\end{array}$ \\
\hline Furosemide & Levothyroxine & Minor & 8 & Not Reported & \multirow{2}{*}{$\begin{array}{l}\text { (Santos-Díaz } \\
\text { et al., 2020) }\end{array}$} \\
\hline Spironolactone & Acenocoumarol & Minor & 6 & Not Reported & \\
\hline \multicolumn{6}{|c|}{ Medscape $(\mathrm{N}=244)$} \\
\hline \multicolumn{6}{|c|}{ Drug Interaction Between ACE Inhibitor and Other Drug $(\mathrm{N}=65)$} \\
\hline Lisinopril & Heparin & Moderate & 34 & Hiperkalemia & \multirow{2}{*}{$\begin{array}{c}\text { (Fasipe, } \\
\text { Akhideno, } \\
\text { Nwaiwu, \& } \\
\text { Adelosoye, } \\
\text { 2017) }\end{array}$} \\
\hline Lisinopril & $\begin{array}{l}\text { Calcium } \\
\text { carbonate }\end{array}$ & Moderate & 31 & $\begin{array}{l}\text { Decreased effect of } \\
\text { Lisinopril }\end{array}$ & \\
\hline \multicolumn{6}{|c|}{ Drug Interactions Between CCB and Other Drug $(\mathrm{N}=32)$} \\
\hline Amlodipine & $\begin{array}{l}\text { Calcium } \\
\text { Carbonate }\end{array}$ & Moderate & 32 & $\begin{array}{c}\text { Decreased effect of } \\
\text { Amlodipine }\end{array}$ & $\begin{array}{l}\text { (Fasipe et } \\
\text { al., 2017) }\end{array}$ \\
\hline \multicolumn{6}{|c|}{ Drug Interaction Between Diuretic and Other Drug $(\mathrm{N}=147)$} \\
\hline Furosemide & Folic acid & Minor & 63 & $\begin{array}{c}\text { Increased renal } \\
\text { clearance of Folic } \\
\text { Acid }\end{array}$ & \multirow{2}{*}{$\begin{array}{l}\text { (Fasipe et } \\
\text { al., 2017) }\end{array}$} \\
\hline Furosemide & $\begin{array}{c}\text { Calcium } \\
\text { carbonate }\end{array}$ & Minor & 49 & $\begin{array}{c}\text { Increased renal } \\
\text { clearance of Calcium }\end{array}$ & \\
\hline \multicolumn{6}{|c|}{ Drug Interaction Between Diuretic and Other Drug $(\mathrm{N}=147)$} \\
\hline Hydrochlorothiazide & Folic acid & Minor & 35 & $\begin{array}{c}\text { Increased renal } \\
\text { clearance of Folic } \\
\text { Acid }\end{array}$ & $\begin{array}{l}\text { (Fasipe et } \\
\text { al., 2017) }\end{array}$ \\
\hline \multicolumn{6}{|c|}{ Omnio $(\mathrm{N}=30)$} \\
\hline \multicolumn{6}{|c|}{ Drug Interaction Between ACE Inhibitor and Other Drug $(\mathrm{N}=13)$} \\
\hline Captopril & Aspirin & Moderate & 2 & $\begin{array}{c}\text { Decreased effect of } \\
\text { Captopril }\end{array}$ & \multirow{5}{*}{$\begin{array}{l}\text { (Okoro \& } \\
\text { Farate, } \\
\text { 2019) }\end{array}$} \\
\hline Captopril & Diclofenac & Moderate & 2 & $\begin{array}{l}\text { Decreased effect of } \\
\text { Captopril and } \\
\text { deterioration of } \\
\text { renal clearance }\end{array}$ & \\
\hline Lisinopril & Aspirin & Moderate & 7 & $\begin{array}{l}\text { Decreased effect of } \\
\text { Lisinopril }\end{array}$ & \\
\hline Lisinopril & Diclofenac & Moderate & 1 & $\begin{array}{l}\text { Decreased effect of } \\
\text { Lisinopril }\end{array}$ & \\
\hline Lisinopril & Naproxen & Moderate & 1 & $\begin{array}{l}\text { Decreased effect of } \\
\text { Lisinopril }\end{array}$ & \\
\hline \multicolumn{6}{|c|}{ Drug Interaction Between Alpha 2 - Adrenergic Agonist and Other Drug $(\mathrm{N}=10)$} \\
\hline Methyldopa & Ferrous sulfate & Moderate & 10 & $\begin{array}{l}\text { Decreased effect of } \\
\text { Methyldopa }\end{array}$ & $\begin{array}{l}\text { (Okoro \& } \\
\text { Farate, } \\
\text { 2019) }\end{array}$ \\
\hline \multicolumn{6}{|c|}{ Drug Interaction Between CCB and Other Drug $(\mathrm{N}=1)$} \\
\hline Amlodipine & Erythromycin & Severe & 1 & $\begin{array}{l}\text { Increased risk of } \\
\text { hypotension, shock, } \\
\text { and sudden death }\end{array}$ & $\begin{array}{l}\text { (Okoro \& } \\
\text { Farate, } \\
\text { 2019) }\end{array}$ \\
\hline \multicolumn{6}{|c|}{ Drug Interaction Between Diuretic and Other Drug $(\mathrm{N}=6)$} \\
\hline Furosemide & Diclofenac & Moderate & 5 & $\begin{array}{c}\text { Decreased diuretic } \\
\text { and } \\
\text { antihypertensive }\end{array}$ & $\begin{array}{l}\text { (Okoro \& } \\
\text { Farate, } \\
\text { 2019) }\end{array}$ \\
\hline
\end{tabular}


effect of

Furosemide

Furosemide

Digoxin Moderate

Increased

arrhythmias

Table 2. Antihypertensive Drug Interactions

\begin{tabular}{|c|c|c|c|c|c|}
\hline \multicolumn{6}{|c|}{ Micromedex $(\mathrm{N}=455)$} \\
\hline \multicolumn{2}{|c|}{ Combination of Drug } & Severity & $\begin{array}{l}\text { Number of } \\
\text { Drug } \\
\text { Interactions }\end{array}$ & Effect & Reference \\
\hline Losartan & Enalapril maleate & Major & 50 & $\begin{array}{c}\text { Syncope, hypotension, } \\
\text { hyperkalemia, acute kidney } \\
\text { injury }\end{array}$ & $\begin{array}{l}\text { (Marquito et } \\
\text { al., 2014) }\end{array}$ \\
\hline Lisinopril & Spironolactone & Major & 4 & Hiperkalemia & $\begin{array}{l}\text { (Saleem et } \\
\text { al., 2017) }\end{array}$ \\
\hline Lisinopril & Losartan & Major & 128 & $\begin{array}{c}\text { Syncope, hypotension, } \\
\text { hyperkalemia, acute kidney } \\
\text { injury }\end{array}$ & $\begin{array}{l}\text { (Busari et } \\
\text { al., 2019) }\end{array}$ \\
\hline Captopril & Furosemide & Moderate & 69 & Postural hypotension & (Marquito et \\
\hline Enalapril & Furosemide & Moderate & 80 & Postural hypotension & al., 2014) \\
\hline Captopril & Furosemide & Moderate & 24 & Postural hypotension & (Saleem et \\
\hline Enalapril & Furosemide & Moderate & 5 & Postural hypotension & al., 2017) \\
\hline \multicolumn{6}{|l|}{ (Continued) } \\
\hline \multicolumn{6}{|c|}{ Micromedex $(\mathrm{N}=455)$} \\
\hline \multicolumn{2}{|c|}{ Combination of Drug } & Severity & $\begin{array}{l}\text { Number of } \\
\text { Drug } \\
\text { Interactions }\end{array}$ & Effect & Reference \\
\hline Atenolol & Prazosin & Moderate & 10 & $\begin{array}{l}\text { Exaggerated hypotensive } \\
\text { response }\end{array}$ & \multirow{3}{*}{$\begin{array}{l}\text { (Saleem et } \\
\text { al., 2017) }\end{array}$} \\
\hline Amlodipine & Atenolol & Moderate & 13 & $\begin{array}{l}\text { Hypotension and/or } \\
\text { bradycardia }\end{array}$ & \\
\hline Furosemide & Lisinopril & Moderate & 11 & Postural hypotension & \\
\hline Lisinopril & Furosemide & Moderate & 43 & Postural hypotension & $\begin{array}{l}\text { (Busari et } \\
\text { al., 2019) }\end{array}$ \\
\hline Furosemide & Hydralazine & Minor & 18 & $\begin{array}{l}\text { The increased diuretic } \\
\text { effect of Furosemide }\end{array}$ & $\begin{array}{l}\text { (Marquito et } \\
\text { al., 2014) }\end{array}$ \\
\hline \multicolumn{6}{|c|}{ Lexicomp $(\mathrm{N}=151)$} \\
\hline Furosemide & Lisinopril & Moderate & 49 & $\begin{array}{l}\text { Acute hypotension and } \\
\text { renal insufficiency }\end{array}$ & \multirow{2}{*}{$\begin{array}{l}\text { (Olumuyiwa } \\
\text { et al., 2017) }\end{array}$} \\
\hline Furosemide & Hydrochlorothiazid & Moderate & 42 & Hypokalemia & \\
\hline Amlodipine & Atenolol & Moderate & 21 & Not reported & \multirow{3}{*}{$\begin{array}{l}\text { (Raddad et } \\
\text { al., 2016) }\end{array}$} \\
\hline Amlodipine & Enalapril & Moderate & 20 & Not reported & \\
\hline Furosemide & Atenolol & Moderate & 19 & Not reported & \\
\hline \multicolumn{6}{|c|}{ Medscape $(\mathrm{N}=91)$} \\
\hline Furosemide & Hydrochlorothiazide & Moderate & 42 & $\begin{array}{l}\text { Hypokalemia, hypotension } \\
\text { and renal insufficiency }\end{array}$ & \multirow{2}{*}{$\begin{array}{l}\text { (Fasipe et } \\
\text { al., 2017) }\end{array}$} \\
\hline Furosemide & Lisinopril & Moderate & 49 & $\begin{array}{l}\text { Hypotension and renal } \\
\text { insufficiency }\end{array}$ & \\
\hline \multicolumn{6}{|c|}{ Omnio $(\mathrm{N}=67)$} \\
\hline Captopril & Furosemide & Moderate & 18 & Postural hypotension & \multirow{5}{*}{$\begin{array}{l}\text { (Okoro \& } \\
\text { Farate, } \\
\text { 2019) }\end{array}$} \\
\hline Captopril & Spironolactone & Moderate & 18 & Hyperkalemia & \\
\hline Lisinopril & Furosemide & Moderate & 21 & Postural hypotension & \\
\hline Lisinopril & Spironolactone & Moderate & 4 & Hyperkalemia & \\
\hline Lisinopril & Torsemide & Moderate & 2 & Postural hypotension & \\
\hline
\end{tabular}




\begin{tabular}{ccccc}
\hline Losartan & Furosemide & Moderate & 2 & Postural hypotension \\
\hline Atenolol & Prazosin & Moderate & 1 & $\begin{array}{c}\text { Increased hypotension } \\
\text { effect of Prazosin }\end{array}$ \\
\hline Atenolol & Nifedipine & Moderate & 1 & $\begin{array}{c}\text { Increased toxic effects of } \\
\text { both drugs }\end{array}$ \\
\hline
\end{tabular}

Table 3. Antihypertensive Drug Classes

\begin{tabular}{|c|c|c|}
\hline Drug Class & Number of Drug Interactions & Percentage \\
\hline Diuretic $^{a}$ & 1.412 & $42,09 \%$ \\
\hline Angiotensin-Converting Enzyme Inhibitor & 1.083 & $32,08 \%$ \\
\hline Calcium-Channel Blocker ${ }^{\mathrm{c}}$ & 334 & $9,96 \%$ \\
\hline Angiotensin II Receptor Blocker ${ }^{\mathrm{d}}$ & 292 & $8,70 \%$ \\
\hline Beta-Blocker ${ }^{\mathrm{e}}$ & 148 & $4,41 \%$ \\
\hline Alpha 2 Adrenergic Agonist $\mathrm{f}^{\mathrm{f}}$ & 57 & $1,70 \%$ \\
\hline Vasodilator $^{\mathrm{g}}$ & 18 & $0,54 \%$ \\
\hline Alpha-1 Blocker ${ }^{\mathrm{h}}$ & 11 & $0,33 \%$ \\
\hline
\end{tabular}

References used: c,e,f(Rama et al., 2012), a,b,c,d,c, (Marquito et al., 2014), a,b,c,e(Raddad et al., 2016), a,b,c,e,h(Saleem et

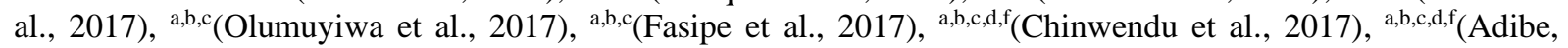
Ewelum, \& Amorha, 2017), ${ }^{\text {a,b,d,e }}$ (Busari et al., 2019), ${ }^{\text {a,b,c,d,e,f,h }}$ (Okoro \& Farate, 2019), ${ }^{\mathrm{a}}$ (Santos-Díaz et al., 2020).

\section{Impact of CKD Condition to the Drug Interaction}

The condition of CKD patients with various comorbid diseases could impact the multiple amounts of drug therapy used by the patients. Polypharmacy is defined as the use of five or more medications (Masnoon, Shakib, Kalisch-Ellett, \& Caughey, 2017). The average number of the drugs combination used reported from the 10 articles was 5 to 15 drugs therapy used per patient (Adibe et al., 2017; Busari et al., 2019; Chinwendu et al., 2017; Fasipe et al., 2017; Marquito et al., 2014; Okoro \& Farate, 2019; Olumuyiwa et al., 2017; Raddad et al., 2016; Rama et al., 2012; Santos-Díaz et al., 2020). Then, several studies also reported that the number of potential drug interactions that occurred is significantly associated with the number of drugs used by the patients (Adibe et al., 2017; Chaliks, 2015; Chinwendu et al., 2017; Okoro \& Farate, 2019; Saleem et al., 2017; Santos-Díaz et al., 2020). Thus, polypharmacy is the contributed factor to the drug interactions, in which the more drug therapy used by the patient, the bigger the risk of drug interaction experienced by CKD patients.

Based on the review from selected ten research articles, it is known that combination therapy used in the treatment of CKD patients with the most prominent to cause drug interaction is from combination with antihypertensive drugs (Adibe, Ewelum, \& Amorha, 2017; Busari et al., 2019; Chinwendu et al., 2017; Ghanbari \& Nagaraju, 2016; Marquito et al., 2014; Okoro \& Farate, 2019; Olumuyiwa et al., 2017; Raddad et al., 2016; Saleem et al., 2017). Three other articles note that drug interactions also involve the antihypertensive drug classes, but the antihypertensive drug classes in these articles are not the cause of most drug interactions ( Fasipe et al., 2017; Rama et al., 2012; Santos-Díaz et al., 2020). Therefore, Table 1 and Table 2 presented potential antihypertensive drug interactions that might be developed either with other drugs (Table 1) or with other antihypertensive drugs (Table 2). Several drug classes in Table 3 showed that the diuretic drug class becomes the highest cause of drug interactions in 
CKD patients. The drug interactions could occur from irrational prescription so that the rational prescription could reduce polypharmacy as a contributed factor to drug interactions (Adibe et al., 2017). Within the body, drug interactions could occur both in pharmacokinetic and pharmacodynamic phases. The pharmacokinetic phase includes the process of absorption, distribution, metabolism, and excretion (ADME). When the drug enters the body, the CKD condition itself will impact the pharmacokinetic aspects. Thus CKD condition will subsequently affect drugs level in the body through ADME processes. For instance, the presence of ammonia formation in CKD patients would be caused gastric urease. This condition made the $\mathrm{pH}$ becomes higher. It leads weak base drugs to be easily absorbed. Furosemide is a weak acid drug, and Digoxin is a weak base drug. Thus, Digoxin absorption is easier than Furosemide, which results in Digoxin level in the blood is higher (Hakim, 2016; Okoro \& Farate, 2019). Also, hypoalbuminemia in CKD patients would decrease drug-protein binding of weak base drugs. This condition will increase the free drug fraction. For instance, the use of weak acid drugs such as Furosemide and Hydrochlorothiazide could promote hypotension and hypokalemia due to the more significant amount of free drug fraction from both drugs as the cause of hypoalbuminemia conditions (Fasipe et al., 2017; Hakim, 2016; Olumuyiwa et al., 2017). Another alteration appeared as the consequences of CKD condition are a declining drug clearance at the liver's metabolism process for several drugs that are metabolized through glucuronidation. A decrease in glomerular filtration rate (GFR) leads to drug clearance declining that is excreted through the kidney and leads to a high drug accumulation level (Hakim, 2016; Rodieux, Wilbaux, van den Anker, \& Pfister, 2015). Drug interactions during the ADME process could promote drug levels higher than the Minimum Toxic Concentration (MTC), leading to drug toxicity, or lower than the Minimum Effective Concentration (MEC), which possibly could not exhibit therapeutic effects. While, as of pharmacodynamics aspects, drug interactions that take place on the receptors lead to synergistic or antagonistic effects, which ultimately impact drugs' efficacy and safety to the patient (Hakim, 2016). Therefore, polypharmacy and alteration in pharmacokinetics due to CKD conditions will develop opportunities to a greater risk of drug interactions.

Impact and Handling of the Antihypertensive Drugs Interaction Effect on the CKD Patients Various types of drugs and a large number of drugs prescribed to CKD patients are necessary to be analyzed in order to assess the possibility of drug interactions occurred. The results obtained from the drug interaction analysis by each program will present all of the potential effects. The most potential drug interaction effects arising between antihypertensive drugs with other drugs classes occurred in CKD patients is a declining of the antihypertensive effect that as counted of 339 drug interactions by the antihypertensive drug classes of ACE inhibitor, CCB, Diuretic, Beta-Blocker, and Alpha-2 Adrenergic Agonist that are shown in Table 1. On the other hand, based on Table 2, the most potential drug interaction effects arising between fellow antihypertensive drug classes are hypotensive effects that 
counted 617 drug interactions. Meanwhile, for drug interactions effect obtained from both interactions either by combination with other drugs classes or interaction between fellow antihypertensive drugs is hyperkalemia effect with as counted of 68 drug interactions in combination with other drugs classes (Table 1) and 204 drug interactions between fellow antihypertensive drugs (Table 2).

The decline of the antihypertensive effect in CKD patients due to drug interactions will ultimately lead to uncontrolled blood pressure. Therefore, monitoring blood pressure in CKD patients is highly recommended to ensure the effectiveness of antihypertensive drugs. Based on KDIGO in 2012, the target blood pressure in non-dialysis CKD patients with or without a history of diabetes mellitus with urinary albumin excretion of less than $30 \mathrm{mg} / 24$ hours is not more than 140/90 $\mathrm{mmHg}$. While the target blood pressure in CKD patients with or without a history of diabetes mellitus with urinary albumin excretion of not less than $30 \mathrm{mg} / 24$ hours is not more than 130/80 mmHg. Hemodialysis patients' blood pressure target still could not be determined due to many factors influenced when undergoing hemodialysis (Becker et al., 2012; Cheung et al., 2019). An increase of systemic blood pressure that exceeds the normal limit will affect glomerular pressure, promoting glomerular damage (Chisholm-Burns et al., 2016). Thus, blood pressure monitoring either after dosage adjustment or drug therapy replacement, diuresis monitoring if diuretics are used, and monitoring kidney function are highly recommended. All of the monitoring activities are necessary to be conducted in aiming to not only inhibit the progression of renal damage but also to reduce the emergence of cardiovascular disease as the highest mortality cases compared to others NCD (Marquito et al., 2014; Pugh, Gallacher, \& Dhaun, 2019; World Health Organization, 2020).

Another effect of drug interaction related to blood pressure is the hypotension effect. Hypotension is systemic blood pressure declining with below $90 / 60 \mathrm{mmHg}$ that will develop to raise dizziness, headache, nausea, fatigue, blurred vision, and several severe symptoms such as chest pain, shortness of breath, irregular heartbeat and can even cause syncope (Sabarirajan \& Shibina, 2020). Postural hypotension is one of the most reported cases of antihypertensive drug interaction effects in CKD patients as the cause of drug interaction between fellow antihypertensive drug classes (Table 2). Postural hypotension is a decrease in systolic blood pressure of at least $20 \mathrm{mmHg}$ or a decrease in diastolic blood pressure of at least ten $\mathrm{mmHg}$ within 3 minutes of standing. A meta-analysis study proved that postural hypotension is significantly associated with an increased risk of all causes of death, the incidence of coronary heart disease, heart failure, and stroke (Ricci et al., 2015). To treat hypotension effect as the result of potential drug interaction is to conduct blood pressure monitoring, evaluate occurred hypotension symptoms, and monitor fluid and body weight regularly for up to 2 weeks after antihypertensive drug dosage adjustment (Marquito et al., 2014).

Hyperkalemia is another effect experienced from antihypertensive drug interaction that may occur in patients with CKD. Hyperkalemia is an elevation of potassium levels in the blood exceeding the normal 
limit. Limitation of potassium level out of the normal level is classified into three categories, mild potassium level with 5.0 to $5.9 \mathrm{mmol} / \mathrm{L}$, moderate with 6.0 to $6.4 \mathrm{mmol} / \mathrm{L}$, and severe with not less than $6.5 \mathrm{mmol} / \mathrm{L}$ accompanied by experienced clinical symptoms by the patient including muscle weakness, paresthesia, paralysis, nausea, shortness of breath, hypotension, and cardiac arrhythmias. Hence, in aiming to suppress the hyperkalemia effect from antihypertensive drug interaction in CKD patients, several monitoring activities are needed to be conducted, including monitoring potassium levels regularly up to 2 weeks after antihypertensive drug dosage adjustment, monitoring kidney function, and also monitoring of heart function in hyperkalemia patients with abnormalities found on the electrocardiogram examination results (Watanabe, 2020).

The result of drug interaction analysis obtained from the analysis program shows drug interaction effects that may occur in the CKD patients, and the drug interactions are classified into a category of severity level. However, there are differences found in the determination of drug interaction classification into certain severity level by each program provided since each drug interaction analysis programs utilizing different the standard, reference, and evidence of analysis in determining drug interaction to certain severity level (Kheshti, Aalipour, \& Namazi, 2016). The drug interaction analysis program results, as shown in Tables 1 and 2 presented the severity level of antihypertensive drug classes interaction with other drug classes. A total of $253(67.83 \%)$ drug interactions were moderate category analyzed with Micromedex; A total of $254(61.20 \%)$ drug interactions were moderate category analyzed with Lexicomp; A total of 147 (60.25\%) drug interactions were minor category analyzed with Medscape, and a total of $29(96.67 \%)$ drug interactions were moderate category analyzed with Omnio. On the other side, drug interaction arising between fellow antihypertensive drugs classes based on drug interaction analysis program result has Micromedex exhibited 255 (56.04\%) drug interactions categorized as moderate, Lexicomp exhibited 151 (100\%) drug interactions categorized as moderate, Medscape exhibited $91(100 \%)$ drug interactions categorized as moderate, and Omnio exhibited 67 (100\%) drug interactions categorized as moderate.

The handling conducted for drug interaction classified in the moderate category is monitoring or replacing drug therapy because drug interaction effects may exacerbate the patient's condition. On the other hand, replacing drug therapy due to drug interaction is unnecessary for drugs classified as a minor drug interaction category. The result of drug interaction program analysis exhibited various severity categories: contraindicated, major, moderate, and minor (Busari et al., 2019). However, in the actual pharmaceutical clinical practice, the severity level of drug interaction is based not only on the drug interaction analysis program but also on the medical expert opinion since both perspectives may be differed due to the patient's clinical status. Therefore, the severity level of drug interaction obtained from the analysis program seems exaggerated because the drug interaction analysis program only identifies drug interaction which might occur without considering the patient clinical condition, and all of the drug 
interaction identified is uncertain occur to the patient (Armahizer, Kane-Gill, Smithburger, Anthes, \& Seybert, 2013). In conclusion, the combination of information from drug interaction analysis program and considering CKD patient medical condition would be better handling drug interactions for CKD patients to prevent kidney function deterioration due to drug interactions complications, ultimately leading to increased morbidity and mortality rates.

\section{CONCLUSION}

CKD is a complex chronic disease that is generally accompanied by various comorbid diseases that can promote drug interactions due to polypharmacy. The effect and category of drug interaction severity could be recognized based on the drug interaction analysis results. Some of the effects of antihypertensive drug interactions that often develop in CKD patients are decreased antihypertensives effect, hypotension, and hyperkalemia, resulting in increasing the risk of morbidity and mortality in CKD patients. Monitoring of blood pressure, diuresis, potassium levels, related symptoms, fluid and body weight, and most importantly monitoring kidney and heart function after dosage adjustment or drug therapy replacement are necessary to maintain CKD patient conditions, prevent exacerbation and obtain optimal drug therapy. The severity level of drug interactions could be considered for handling potential drug interactions, but it needs to be accompanied by knowledge and skills in understanding the patient's clinical condition.

\section{ACKNOWLEDGEMENT}

The authors especially thank the Faculty of Pharmacy, Padjadjaran University and RSUP. Dr. Hasan Sadikin Bandung for support during the review and preparation of the manuscript.

\section{CONFLICT OF INTEREST}

There are no conflicts of interest.

\section{REFERENCES}

Adibe, M. O., Ewelum, P. C., \& Amorha, K. C. (2017). Evaluation of drug-drug interactions among patients with chronic kidney disease in a South-Eastern Nigeria tertiary hospital: a retrospective study. Pan African Medical Journal, 28, 199. https://doi.org/10.11604/pamj.2017.28.199.13622

Armahizer, M. J., Kane-Gill, S. L., Smithburger, P. L., Anthes, A. M., \& Seybert, A. L. (2013). Comparing Drug-Drug Interaction Severity Ratings between Bedside Clinicians and Proprietary Databases. ISRN Critical Care, 2013, 1-6. https://doi.org/10.5402/2013/347346

Becker, G. J., Wheeler, D. C., De Zeeuw, D., Fujita, T., Furth, S. L., Holdaas, H., ... Zoccali, C. (2012). Kidney disease: Improving global outcomes (KDIGO) blood pressure work group. KDIGO clinical practice guideline for the management of blood pressure in chronic kidney disease. Kidney International Supplements, 2(5), 337-414. https://doi.org/10.1038/kisup.2012.46 
Belaiche, S., Romanet, T., Allenet, B., Calop, J., \& Zaoui, P. (2012). Identification of drug-related problems in ambulatory chronic kidney disease patients: a 6-month prospective study. $J$ Nephrol, 25(5), 782-788.

Bikbov, B., Purcell, C. A., Levey, A. S., Smith, M., Abdoli, A., Abebe, M., .. Murray, C. J. L. (2020). Global, regional, and national burden of chronic kidney disease, 1990-2017: a systematic analysis for the Global Burden of Disease Study 2017. The Lancet, 395(10225), 709-733. https://doi.org/10.1016/S0140-6736(20)30045-3

Busari, A. A., Oreagba, I. A., Oshikoya, K. A., Kayode, M. O., \& Olayemi, S. O. (2019). High Risk of Drug-drug interactions among Hospitalized Patients with kidney Diseases at a Nigerian Teaching Hospital: A Call for Action. Nigerian Medical Journal: Journal of the Nigeria Medical Association, 60(6), 317. https://doi.org/10.4103/nmj.NMJ_2_19

Chaliks, R. (2015). Factors Influence the Potential Drug Interaction Occurence among Hospitalized Patients with Cronic Kidney Disease at Labuang Baji Hospital Makassar. International Journal of Sciences: Basic and Applied Research, 24, 376-383.

Cheung, A. K., Chang, T. I., Cushman, W. C., Furth, S. L., Ix, J. H., Pecoits-Filho, R., ... Williamson, J. D. (2019). Blood pressure in chronic kidney disease: conclusions from a Kidney Disease: Improving Global Outcomes (KDIGO) Controversies Conference. Kidney International, 95(5), 1027-1036. https://doi.org/10.1016/j.kint.2018.12.025

Chinwendu, A. K., Joda, A. E., Oyetunde, O. O., \& Udezi, W. A. (2017). Evaluation of drug-drug interactions among chronic kidney disease patients of nephrology unit in the University of Nigeria Teaching Hospital, Ituku-Ozalla, Enugu State. Journal of Basic and Clinical Pharmacy, 8, S049-S053.

Chisholm-Burns, M. A., Schwinghammer, T. L., Wells, B. G., Malone, P. M., Kolesar, J. M., \& DiPiro, J. T. (Eds.). (2016). Pharmacotherapy Principles \& Practice (Fourth). United States: McGrawHill Education.

Cozzolino, M., Mangano, M., Stucchi, A., Ciceri, P., Conte, F., \& Galassi, A. (2018). Cardiovascular disease in dialysis patients. Nephrology Dialysis Transplantation, 33(suppl_3), iii28-iii34. https://doi.org/10.1093/ndt/gfy174

Fasipe, O. J., Akhideno, P. E., Nwaiwu, O., \& Adelosoye, A. A. (2017). Assessment of prescribed medications and pattern of distribution for potential drug-drug interactions among chronic kidney disease patients attending the Nephrology Clinic of Lagos University Teaching Hospital in SubSaharan West Africa. Clinical Pharmacology: Advances and Applications, 9, 125. https://doi.org/10.2147/CPAA.S147835

Ghanbari, Y., \& Nagaraju, K. (2016). Identifying Drug-Drug Interaction Among Chronic Kidney Disease Patients in Tertiary Care Hospital. International Research Journal of Pharmacy, 7(7), 54- 
56. https://doi.org/10.7897/2230-8407.07785

Hakim, L. (2016). Farmakokinetik Klinik (First; I. Wardini, N. H. Riza, \& A. Bimantara, eds.). Yogyakarta: Bursa Ilmu.

Hassan, Y., Al-Ramahi, R., Aziz, N. A., \& Ghazali, R. (2009). Drug use and dosing in chronic kidney disease. Annals Academy of Medicine Singapore, 38(12), 1095.

Kheshti, R., Aalipour, M., \& Namazi, S. (2016). A comparison of five common drug-drug interaction software programs regarding accuracy and comprehensiveness. Journal of Research in Pharmacy Practice, 5(4), 257. https://doi.org/10.4103/2279-042X.192461

Maas, R., \& Böger, R. H. (2003). Antihypertensive therapy: special focus on drug interactions. Expert Opinion on Drug Safety, 2(6), 549-579.

Marquito, A. B., Fernandes, N. M. da S., Colugnati, F. A. B., \& Paula, R. B. de. (2014). Identifying potential drug interactions in chronic kidney disease patients. J. Bras. Nefrol., 36(1), 26-34. https://doi.org/10.5935/0101-2800.20140006

Masnoon, N., Shakib, S., Kalisch-Ellett, L., \& Caughey, G. E. (2017). What is polypharmacy? A systematic review of definitions. BMC Geriatrics, 17(1), 1-10.

Okoro, R. N., \& Farate, V. T. (2019). Evaluation of potential drug-drug interactions among patients with chronic kidney disease in northeastern Nigeria. African Journal of Nephrology, 22(1), 77-81.

Olumuyiwa, J. F., Akinwumi, A. A., Ademola, O. A., Oluwole, B. A., \& Ibiene, E. O. (2017). Prevalence and pattern of potential drug-drug interactions among chronic kidney disease patients in southwestern Nigeria. Niger Postgrad Med J, 24(2), 88-92.

Pugh, D., Gallacher, P. J., \& Dhaun, N. (2019). Management of Hypertension in Chronic Kidney Disease. Drugs, 79(4), 365-379. https://doi.org/10.1007/s40265-019-1064-1

Raddad, A. R., Rashed, A. O., Bsharat, A., Abu-Ghazaleh, D., Yasin, E., \& Shehab, O. (2016). Evaluation of potential drug-drug interactions among Palestinian hemodialysis patients. BMC Nephrology, 17(1), 96. https://doi.org/10.1186/s12882-016-0317-4

Rama, M., Viswanathan, G., Acharya, L. D., Attur, R. P., Reddy, P. N., \& Raghavan, S. V. (2012). Assessment of Drug-Drug Interactions among Renal Failure Patients of Nephrology Ward in a South Indian Tertiary Care Hospital. Indian Journal of Pharmaceutical Sciences, 74(1), 63-68. https://doi.org/10.4103/0250-474X.102545

Ricci, F., Fedorowski, A., Radico, F., Romanello, M., Tatasciore, A., Di Nicola, M., ... De Caterina, R. (2015). Cardiovascular morbidity and mortality related to orthostatic hypotension: a meta-analysis of prospective observational studies. European Heart Journal, 36(25), 1609-1617. https://doi.org/10.1093/eurheartj/ehv09

Rodieux, F., Wilbaux, M., van den Anker, J. N., \& Pfister, M. (2015). Effect of kidney function on drug kinetics and dosing in neonates, infants, and children. Clinical Pharmacokinetics, 54(12), 1183- 
1204. https://doi.org/10.1007/s40262-015-0298-7

Sabarirajan, S., \& Shibina, K. (2020). Hypotension and homoeopathic management. International Journal of Homoeopathic Sciences, 4(2), 122-124.

Saleem, A., Masood, I., \& Khan, T. M. (2017). Clinical relevancy and determinants of potential drugdrug interactions in chronic kidney disease patients: results from a retrospective analysis. Integrated Pharmacy Research \& Practice, 6, 71-77. https://doi.org/10.2147/IPRP.S128816

Santos-Díaz, G., Pérez-Pico, A. M., Suárez-Santisteban, M. Á., García-Bernalt, V., Mayordomo, R., \& Dorado, P. (2020). Prevalence of Potential Drug-Drug Interaction Risk among Chronic Kidney Disease Patients in a Spanish Hospital. Pharmaceutics, 12(8). https://doi.org/10.3390/pharmaceutics12080713

Watanabe, R. (2020). Hyperkalemia in chronic kidney disease. Revista Da Associacao Medica Brasileira, 66(Suppl 1), 31-36. https://doi.org/10.1590/1806-9282.66.S1.31

World Health Organization. (2020). World Health Statistics 2020: Monitoring health for the SDGs, Sustainable Development Goals (Vol. 21). https://doi.org/10.1155/2010/706872 